\title{
Involvement of a putative molybdenum enzyme in the reduction of selenate by Escherichia coli
}

\author{
Magali Bébien, ${ }^{1}$ Julia Kirsch, ${ }^{1}$ Vincent Méjean ${ }^{2}$ and André Verméglio ${ }^{1}$
}

Author for correspondence: André Verméglio. Tel: +33 442254630. Fax: +33442254701.

e-mail: avermeglio@cea.fr

1 CEA/Cadarache-DSVDEVM-Laboratoire de Bioénergétique Cellulaire, Université de la Méditerranée CEA 1000 13108 Saint-Paul-lezDurance Cedex, France

2 Laboratoire de Chimie Bactérienne, Institut de Biologie Structurale et Microbiologie, CNRS 31 Chemin Joseph Aiguier, BP 71, 13402 Marseille Cedex 20, France

\begin{abstract}
Selenium oxyanions, particularly selenite, can be highly toxic to living organisms. Few bacteria reduce both selenate and selenite into the less toxic elemental selenium. Insights into the mechanisms of the transport and the reduction of selenium oxyanions in Escherichia coli were provided by a genetic analysis based on transposon mutagenesis. Ten mutants impaired in selenate reduction were analysed. Three of them were altered in genes encoding transport proteins including a porin, an inner-membrane protein and a sulfate carrier. Two mutants were altered in genes required for molybdopterin biosynthesis, strongly suggesting that the selenate reductase of $E$. coli is a molybdoenzyme. However, mutants deleted in various oxomolybdenum enzymes described so far in this species still reduced selenate. Finally, a mutant in the gene ygfK encoding a putative oxidoreductase was obtained. This gene is located upstream of ygfN and ygfM in the ygfKLMN putative operon. YgfN and YgfM code for a molybdopterin-containing enzyme and a polypeptide carrying a FAD domain, respectively. It is therefore proposed that the selenate reductase of $E$. coli is a structural complex including the proteins YgfK, YgfM and YgfN. In addition, all the various mutants were still able to reduce selenite into elemental selenium. This implies that the transport and reduction of this compound are clearly distinct from those of selenate.
\end{abstract}

Keywords: molybdenum iron-sulfur protein, oxyanion reduction, selenite

\section{INTRODUCTION}

Selenium is an essential trace nutrient for most living organisms (McKeehan et al., 1976; Shamberger, 1983). Small amounts of selenium are required to synthesize the amino acid selenocysteine present in a few proteins such as formate dehydrogenases and glycine reductase in prokaryotes (reviewed by Stadtman, 1996). In aerated environments, selenium occurs predominantly and naturally as the high-valence soluble forms selenate $\left(\mathrm{SeO}_{4}^{2-},+\mathrm{VI}\right)$ and selenite $\left(\mathrm{SeO}_{3}^{2-},+\mathrm{IV}\right)$. These inorganic oxidized forms are abundant in some habitats, particularly through contamination of soil and drainage waters as a result of widespread use in industrial and agricultural processes (Losi \& Frankenberger, 1997). High concentrations of selenium oxyanions are highly

Abbreviations: EDX, energy-dispersive X-ray; TMAO, trimethylamine $N$ oxide. toxic and mutagenic for bacteria and mammals (Noda et al., 1979; Stadtman, 1974). Consequently, selenium accumulation can cause important ecological problems such as in the Kesterson reservoir, in the San Joaquin Valley (California, USA), where selenium concentration resulted in extensive deformities and deaths in waterfowl and other wildlife (Ohlendorf \& Santolo, 1994; Saiki \& Lowe, 1987).

In the biogeochemical cycle of selenium, various redox reactions are carried out by microorganisms. Several bacteria, including Escherichia coli (Turner et al., 1998) are able to reduce both selenate and selenite into elemental selenium $\left(\mathrm{Se}^{0}\right)$, while certain species like Rhodobacter sphaeroides (Bebien et al., 2001; Van Fleet-Stalder et al., 2000) or Ralstonia metallidurans (Roux et al., 2001) reduce only selenite. The reduction of the bioavailable selenium oxyanions into elemental selenium, which is insoluble and non-toxic, is of great interest for bioremediation. Particles of elemental selenium accumulate in the periplasm (Gerrard et al., 
Table 1. E. coli strains used in this study and their sources

\begin{tabular}{|c|c|c|c|}
\hline Strains & Relevant genotype or characteristics & Phenotype* & Source/reference \\
\hline JCB387 & RV $\Delta n i r$ & Lacks NADH-nitrite reductase $\left(\mathrm{Nir}^{-}\right)$ & Hussain et al. (1994) \\
\hline JCB3882 & JCB387 fdnGfdhFfdo & Lacks all formate dehydrogenases & Darwin et al. (1993) \\
\hline LCB2048 & LCB320 nar $G::$ kan nar $Z:: \Omega$ & $\begin{array}{l}\text { Defective in two membrane-associated } \\
\text { nitrate reductases } A \text { and } Z\end{array}$ & Potter et al. (2000) \\
\hline JCB20480 & LCB2048 napA::ery & Lacks all three nitrate reductases & Potter et al. (2000) \\
\hline MC4100 & $\operatorname{araD139} \Delta($ lacIPOZYA-argF $) U 169$ rpsL thi & Parental strain & Laboratory collection \\
\hline LCB620 & MC4100 torA8:: MudII 1734 (tor $A^{\prime}-{ }^{\prime}$ lacZ) & Periplasmic TMAO-deficient $\left(\right.$ TorA $\left.^{-}\right)$ & Ansaldi et al. (1999) \\
\hline DSS401 & MC4100 dms::kan & Membrane-bound DMSO-deficient (Dms $\left.{ }^{-}\right)$ & V. Méjean† \\
\hline RK4353 & Parent of RK strains & Parental strain & G. Giordano† \\
\hline RK5200 & RK4353 chlA200:: Mutcs & Defective in MPT, MGD synthesis $\left(\mathrm{ChlA}^{-}\right)$ & Stewart \& MacGregor (1982) \\
\hline RK5202 & RK4353 chlD202:: Mutcs & Defective in molybdate uptake $\left(\mathrm{ChlD}^{-}\right)$ & Stewart \& MacGregor (1982) \\
\hline RK5208 & RK4353 chlB208:: Mutcs & Defective in MGD synthesis $\left(\mathrm{ChlB}^{-}\right)$ & Stewart \& MacGregor (1982) \\
\hline AW3110 & $\mathrm{K} 12 \mathrm{~F}^{-} \mathrm{IN}(r r n D-r r n E) \Delta a r s:$ cam & Lacks arsenate reductase $\left(\mathrm{Ars}^{-}\right)$ & Carlin et al. (1995) \\
\hline DHB4 & $\begin{array}{l}\mathrm{F}^{\prime} \text { lac-pro lacl }{ }^{\mathrm{q}} / \Delta(\text { ara-leu }) 7697 \text { araD139 } \\
\Delta \text { lacX74 galE galK rpsL phoR } \\
\Delta(\text { phoA)PvuII } \Delta \text { malF3 thi }\end{array}$ & Parental strain & Prinz et al. (1997) \\
\hline WP758 & DHB4 gshA20::kan & Lacks glutaredoxin & Prinz et al. (1997) \\
\hline
\end{tabular}

* MPT, molybdopterin; MGD, molybdopterin guanine dinucleotide.

†Laboratoire de Chimie Bactérienne, Institut de Biologie Structurale et Microbiologie, Marseille, France.

1974), in the cytoplasm (Silverberg et al., 1976) or outside the cell (Yamada et al., 1997), depending upon the species. The biological mechanisms and enzymes involved in the reduction of selenate and selenite are still to be characterized. Up to now, a specific selenate reductase has only been purified from Thauera selenatis (Schröder et al., 1997), a species that uses selenate or selenite as electron acceptors in the first steps of an anaerobic respiratory process similar to denitrification (DeMoll-Decker \& Macy, 1993). This highly specific reductase does not reduce nitrate, nitrite, chlorate or sulfate. The enzyme has an apparent molecular mass of $180 \mathrm{kDa}$ and is composed of three subunits. It contains a cytochrome $b$, a molybdenum cofactor and two putative $[\mathrm{Fe}-\mathrm{S}]$ centres. In addition, the second step of selenate reduction to selenium - the reduction of selenite to $\mathrm{Se}^{0}$ - is catalysed by the nitrite reductase in $T$. selenatis. This has been clearly demonstrated by the inability of a mutant defective in this enzyme to sustain selenite reduction (DeMoll-Decker \& Macy, 1993). Other evidence for the involvement of the denitrification enzymes in selenate or selenite reduction comes from the observation that in situ nitrate and selenate reductions present similar profiles as a function of the sediment depth (Oremland, 1994). Moreover, in vitro studies have shown that soluble or membranous nitrate reductases of different species possess selenate reductase activity (Avazeri et al., 1997). Extensive in vitro studies on the mechanisms of selenite reduction have shown the involvement of thiol groups of thiol-containing molecules such as glutathione (GSH) leading to the production of the intermediate metabolites selenodiglutathione (GS-Se-SG), glutathioselenol (GS-SeH) and hydrogen selenide $\left(\mathrm{HSe}^{-}\right)$and finally to elemental selenium (Ganther, 1968; Kice et al., 1980). One consequence of these reactions is the production of the highly toxic hydrogen peroxide $\left(\mathrm{H}_{2} \mathrm{O}_{2}\right)$ and superoxide $\left(\mathrm{O}_{2}^{--}\right)$suspected of causing damage to the cell membranes and DNA (Kramer \& Ames, 1988; Seko \& Imura, 1997). Recently, we have described the in vivo enhancement of the synthesis of enzymes associated with oxidative stress in response to selenate or selenite addition in both E. coli (Bebien et al., 2002) and the photosynthetic bacterium $R b$. sphaeroides (Bebien et al., 2001). To prevent acute and chronic toxicity of the soluble selenium compounds, it is important to establish the molecular and physiological basis of the detoxification and removal of selenium oxyanions.

In the present work, molecular genetic strategies have been used to investigate the mechanisms responsible for the reduction of selenium oxyanions, in particular selenate, in E. coli.

\section{METHODS}

Bacterial strains and growth conditions. All strains used in this study are E. coli K-12 derivates, as listed in Table 1. Bacterial cultures were grown aerobically at $37^{\circ} \mathrm{C}$ in liquid Luria-Bertani (LB) broth in $250 \mathrm{ml}$ Erlenmeyer flasks containing $100 \mathrm{ml}$ medium inoculated with $10 \%(\mathrm{v} / \mathrm{v})$ of an overnight culture in a rotary shaker (170 r.p.m.) or on agar

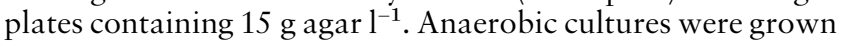
in full cap tubes containing LB medium, and when necessary, $\mathrm{KNO}_{3}(20 \mathrm{mM})$ was added. When required, the medium was supplemented with chloramphenicol $\left(12.5 \mu \mathrm{g} \mathrm{ml}^{-1}\right)$, tetracycline $\left(12 \mu \mathrm{g} \mathrm{ml}^{-1}\right)$ or kanamycin $\left(50 \mu \mathrm{g} \mathrm{ml}^{-1}\right)$.

Preparation of membrane fractions and enzymic activity. Cells were resuspended in ice-cold $50 \mathrm{mM}$ Tris/ $\mathrm{HCl}, \mathrm{pH} 8$, 
containing $1 \mathrm{mM}$ 4-(2-aminoethyl) benzenesulfonyl fluoride and were disrupted using a French press $\left(1.4 \times 10^{8} \mathrm{~Pa}\right)$. Unbroken cells were removed by centrifugation at $20000 \mathrm{~g}$ $\left(4{ }^{\circ} \mathrm{C}\right)$ for $10 \mathrm{~min}$. The soluble and membrane fractions were then separated by ultracentrifugation for $1 \mathrm{~h}$ at $150000 \mathrm{~g}$ $\left(4^{\circ} \mathrm{C}\right)$. The pellet (membrane fractions) was resuspended in $0.01 \%$ Triton X-100 in $50 \mathrm{mM}$ Tris $/ \mathrm{HCl}, \mathrm{pH} \mathrm{8}$, and proteins were separated on a $8 \%$ non-denaturing electrophoresis gels containing $0 \cdot 1 \%$ Triton X-100. Detection of nitrate reductase was carried out by the staining method described previously (Iobbi-Nivol et al., 1990).

Screening procedure to isolate mutants defective in selenate reduction and DNA manipulation. The random mini-Tn10 transposition mutagenesis was described by Ansaldi et al. (1999). Tn10 insertion mutants were grown on LB plates containing chloramphenicol $\left(12.5 \mu \mathrm{g} \mathrm{ml}^{-1}\right)$ and incubated for 2-3 days at $37^{\circ} \mathrm{C}$. Mutants were subsequently plated on LB medium containing $\mathrm{SeO}_{4}^{2-}(1 \mathrm{mM})$ to screen the mini- $\mathrm{Tn} 10$ insertions for lack of selenate reduction ability. The location of the insertions was analysed using a rapid inverse PCR method (Ansaldi et al., 1999). The PCR product was purified from an agarose gel using a PCR purification kit (QIAquick, QIAgen). DNA sequencing was performed with an ABI apparatus (ABI Prism 310, Applied Biosystems). DNA and protein sequence analyses were performed using software tools (ExPASy).

Minimal inhibitory concentration (MIC) determination. Determination of the MIC, defined as the lowest concentration of inhibitor preventing growth of E. coli strains at $37^{\circ} \mathrm{C}$ on agar plates, was performed as described previously (Avazeri et al., 1997).

Electron microscopy and X-ray analysis. Cells were fixed in $2.5 \%$ glutaraldehyde and $0 \cdot 1 \mathrm{M}$ cacodylate buffer, $\mathrm{pH} 7 \cdot 1$, for $30 \mathrm{~min}$. After washing twice with the same medium, they were post-fixed in $1 \% \mathrm{OsO}_{4}$ in $0.02 \mathrm{M}$ cacodylate buffer, $\mathrm{pH} 7 \cdot 1$, for $1 \mathrm{~h}$, and subsequently dehydrated with a graded ethanol/ water series and embedded in low-viscosity epoxy resin (Epon). Microtome-cut thin sections were contrasted with uranyl acetate and lead citrate, as described by Hess (1966), and observed with a Philips CM 120 transmission electron microscope. For energy-dispersive X-ray (EDX) analysis, thin sections were applied to carbon-coated transmission electron microscopy grids and dried at room temperature. The EDX analysis was performed with a JEOL model $2010 \mathrm{~F}$ electron microscope operating at $200 \mathrm{kV}$ and equipped with an EDAXKEVEX microanalysis system.

Chemicals. Sodium selenate and sodium selenite were purchased from Sigma-Aldrich. The oligonucleotides used were purchased from Genome express. All other chemicals used were analytical grade.

\section{RESULTS AND DISCUSSION}

\section{Isolation of mutants defective in selenate reduction}

Aerobic (Fig. 1A) and anaerobic (data not shown) cultures of E. coli reduce both selenate and selenite to red amorphous metallic selenium $\left(\mathrm{Se}^{0}\right)$. The cytoplasmic accumulation of this compound is demonstrated by the characteristic EDX spectrum of high-electron-density particles, which shows all the peaks of selenium at 1.37, 11.22 and $12.49 \mathrm{keV}$ (Fig. 1C). In agreement with previous reports (Silverberg et al., 1976), no deposits were observed in the periplasmic spaces of bacterial preparations.

To gain an insight into the mechanisms of the reduction of selenium oxyanions and to identify the enzyme(s) involved in these reduction processes, we have used a global genetic approach. The formation of coloured insoluble selenium as a product of selenate or selenite reduction was used to screen mutants affected in this process from a random mini-Tn10 E. coli insertion library. Clones unable to reduce oxyanions form white colonies on selenate- or selenite-containing media, while clones unaffected in the assimilation and reduction of selenium oxyanions turn bright red owing to the formation of metallic selenium. On the basis of this screening, 10 mutants defective in selenate reduction were isolated out of approximately 12000 clones of the transposon library. Insertions were mapped using a rapid inverse PCR with mini-Tn10 based primers (see Methods), and then the transposon flanking regions were sequenced to identify the affected loci. Insertions that abolish selenate reduction could be sorted into four different classes (Table 2). We distinguished mutants altered (1) in unclassified genes with unknown function $(y h c E, y o h C, r h s A, y f e U)$, (2) in genes involved in transport systems $(n m p C, y b a T, c y s A)$, (3) in genes required for biosynthesis of the molybdopterin cofactor (moeAB locus, yehH named molR) and (4) in the $y g f K$ gene encoding a putative oxidoreductase. The precise locations of these insertions are summarized in Table 2. Strikingly, all these mutants were still able to reduce selenite or tellurite $\left(\mathrm{TeO}_{3}^{2-}\right)$. This observation implies that these different mutants are only affected in the reduction of selenate to selenite, i.e. in the first step of the reduction process.

Surprisingly, we were unable to select mutants impaired in selenite reduction using a similar screening approach. Several non-exhaustive hypotheses could be proposed to explain this observation. On the one hand, selenite is more toxic than selenate, as demonstrated by the MIC in aerobic growth conditions of $7 \mathrm{mM}$ and greater than $300 \mathrm{mM}$, respectively. Therefore, impairing the reduction pathway of selenite might have rendered the mutants extremely sensitive to this compound and thus even unable to grow on media containing selenite at the lowest concentration $(10 \mu \mathrm{M})$ we used. On the other hand, it is possible that selenium precipitation is the result of two or more distinct reduction pathways. In particular, selenite reduction may be mediated by nonenzymic reactions. Indeed, in vitro studies have shown that selenite reduction involves reactions with thiol groups of thiol-containing proteins and molecules such as reduced glutathione (Ganther, 1968; Kice et al., 1980), leading to the production of elemental selenium. Although a strain devoid of glutathione $(\Delta g s h A)$ still reduces selenite (data not shown), this does not exclude the possibility that other thiol-containing compounds and proteins are involved in such a process. Finally, one cannot rule out the possibility that the genes encoding the proteins involved in selenite reduction pathway are duplicated, therefore compensating for mutations. 
A
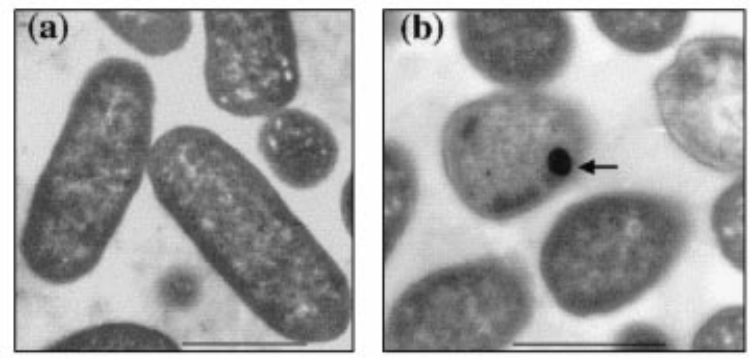

B
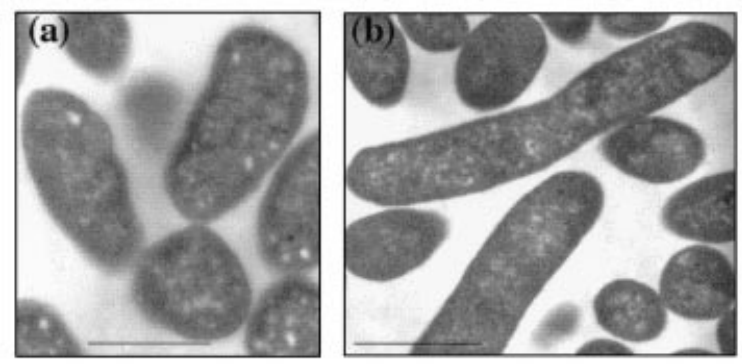

C

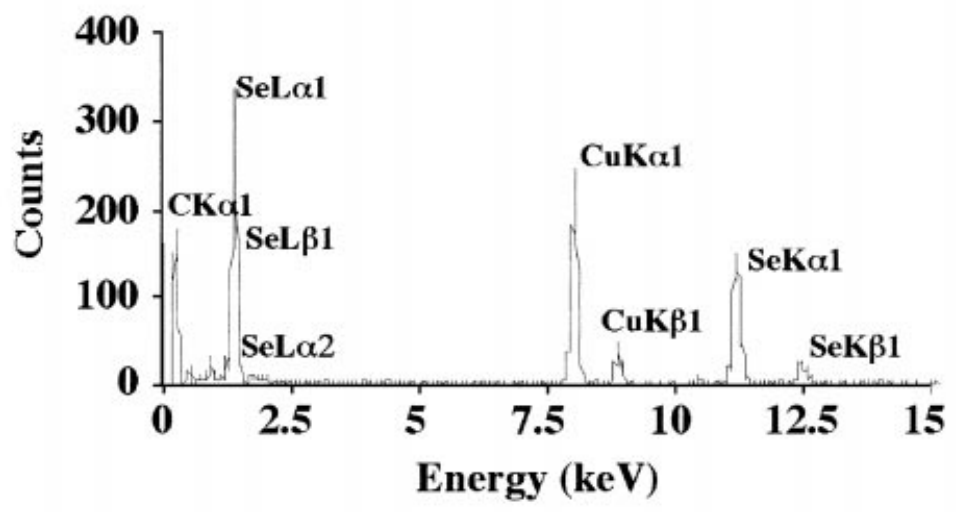

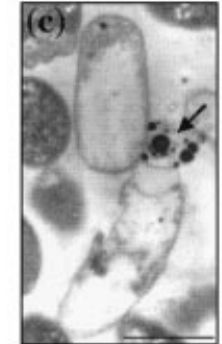

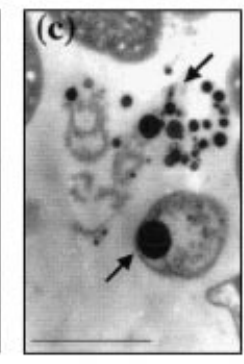

Fig. 1. Thin-section micrographs of $E$. coli (A) parental strain LCB620 and (B) mutant defective in molybdopterin cofactor biosynthesis LBC010. The strains were grown under aerobic conditions in the absence (a) or the presence (b) of $2 \mathrm{mM} \mathrm{SeO}_{4}^{2-}$ or (c) $2 \mathrm{mM} \mathrm{SeO}{ }_{3}^{2-}$. Bars, $1 \mu \mathrm{m}$. (C) EDX spectrum of electron-dense particles indicated by arrows in $(A)$ and $(B)$.

Table 2. Identification of selenate reduction deficient mutants

\begin{tabular}{|llll|}
\hline Mutant name & $\begin{array}{c}\text { Calculated map location } \\
(\mathbf{m i n})\end{array}$ & Protein name & \\
\hline LBC01 & $11 \cdot 03$ & Function \\
LBC03 & $12 \cdot 39$ & YbaT & Probable amino acid or metabolite transport protein \\
LBC07 & $54 \cdot 70$ & CysA & Outer-membrane porin protein \\
LBC05 & $72 \cdot 49$ & YhcE & Sulfate transport ATP-binding protein \\
LBC018 & $47 \cdot 92$ & YohC & Unknown \\
LBC034 & $81 \cdot 04$ & RhsA & Unknown \\
LBC08 & $54 \cdot 83$ & YfeU & Unknown \\
LBC010 & $18 \cdot 62$ & MoeA & Molybdopterin biosynthsesis, chlorate resistance \\
LBC023 & $47 \cdot 30$ & MolR & Molybdate metabolism regulator \\
LBC025 & $64 \cdot 97$ & YgfK & Putative oxidoreductase, Fe-S subunit \\
\hline
\end{tabular}

\section{Transport of selenate}

One mutant that is unable to reduce selenate is affected in the sulfate uptake ATP-binding protein (CysA). This result was not surprising, since previous studies have clearly demonstrated that selenate enters the cell through this system in E. coli (Linblow-Kull et al., 1985) and Saccharomyces cerevisiae (Smith et al., 1995). In addition, we found that mini-Tn10 insertions in $y b a T$ or $n m p C$ genes, encoding a putative amino acid or metabolite transport protein probably located in the inner membrane and an outer-membrane porin protein (Table 
2), respectively, inhibited the reduction of selenate without any change to the growth rate. This implies that, in addition to the sulfate permease system, these two proteins are essential for the transport of selenate from the outside of the bacteria into their cytoplasm.

\section{Requirement of a molybdenum-containing enzyme for selenate reductase activity}

The mutants moeA and molR are both defective in genes encoding enzymes required for biosynthesis of the molybdenum cofactor, which consists in the most simple form of a pterin complexed to molybdenum (Table 2). This strongly suggests that the enzyme involved in the reduction of selenate into selenite is a molybdenumcontaining enzyme. To test this hypothesis further, we measured the selenate-reducing capability of a series of mutants deleted in genes involved in the synthesis of the molybdopterin (MPT) cofactor. The two mutants RK5200 and RK5202 (Table 1), deleted in moa and mob operons (formerly designated $c h l A$ and $c h l B$ ), responsible for biosynthesis of the mononucleotide and dinucleotide forms of the pterin cofactor (reviewed by Hille, 1996), respectively, were unable to reduce selenate. In addition, selenate reduction was not observed for the mutant RK5208 defective in mod locus (chlD in the former nomenclature), which encodes a high-affinity molybdate uptake system. However, in agreement with previous reports, showing that molybdate can enter the cell by other pathways (Rosentel et al., 1995), the addition of high concentrations of molybdate to the growth medium restored molybdoenzyme activities such as nitrate reductase activity (Rosentel et al., 1995; this work) and, consequently, the capability to reduce selenate. These results demonstrate the involvement of a molybdoenzyme in the reduction of selenate to selenite.

E. coli contains several molybdopterin guanine dinucleotide (MGD)-dependent enzymes including the arsenate, DMSO, TMAO and nitrate reductases and the formate dehydrogenases. Particular attention was paid to the possible role of the different nitrate reductases in the selenate reduction. Indeed, previous in vitro studies have demonstrated that the membrane-associated nitrate reductases of E. coli (NRA, NRZ) were able to reduce selenate with benzyl viologen as electron donor (Avazeri et al., 1997). More recently, this phenomenon was described to be a general feature of various soluble or membrane-bound nitrate reductases of numerous denitrifying species (Sabaty et al., 2001). However, a mutant of E. coli deleted in both membrane-bound reductases NRA and NRZ (LCB2048) still reduces selenate, resulting in the accumulation of elemental selenium. In addition to the two membrane-bound nitrate reductases NRA and NRZ, E. coli harbours a dissimilatory periplasmic nitrate reductase (Nap system, reviewed by Moreno-Vivian et al., 1999). The role of this soluble enzyme in the reduction of selenate was tested using a strain lacking both nar and nap genes (JCB20480). This triple mutant turned red, like the wild-type, in the presence of selenate, resulting from the reduction of

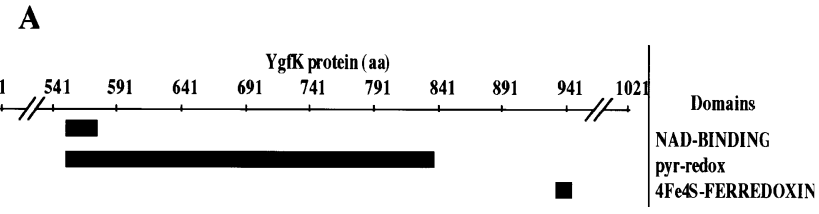

B

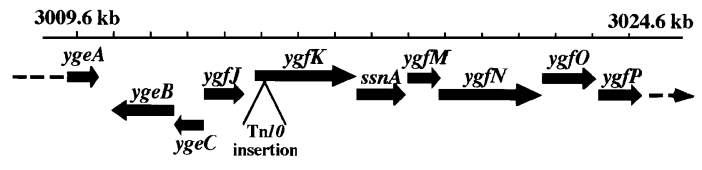

Fig. 2. (A) Domain structures of YgfK predicted from the amino acid sequence of the protein (length 1032 aa). This protein possesses a NAD-binding domain, a pyridine nucleotide-disulfide redox (pyr-redox) domain and an $\mathrm{Fe}-\mathrm{S}$ cluster, which are approximately located in this graphical view. (B) Arrangement of genes in the region of $y g f K$ from 3009.6 to $3024 \cdot 6 \mathrm{~kb}$.

this oxyanion into metallic selenium. Furthermore, the MIC of selenate is identical for the wild-type and the $\Delta$ nar $\Delta$ nap or $\Delta$ nar mutants.

In addition to nitrate reductases, we have observed that DMSO and TMAO reductases also possess a selenate reductase activity in vitro with benzyl viologen as electron donor (data not shown). This in vitro selenate reductase activity, however, is 10-fold lower than the selenate reductase activity of nitrate reductases. Mutants altered in DMSO, TMAO or arsenate reductases, or in formate dehydrogenases, were still able to reduce selenate into metallic selenium with intracytoplasmic accumulation (data not shown). We therefore conclude that, although some of the molybdoenzymes of E. coli possess selenate reductase activity in vitro, their contribution to the in vivo reduction of selenate is low or nil.

This series of results provides evidence that the reduction of selenate in E. coli is catalysed, as demonstrated for $T$. selenatis (Schröder et al., 1997), by a molybdoenzyme. In addition, this enzyme differs from various mononuclear oxomolybdenum enzymes described so far in E. coli.

\section{Identification of a putative selenate reductase in $E$. coli}

One of the mutants unable to reduce selenate into selenite was altered in the synthesis of a putative oxidoreduction enzyme, denoted YgfK. The alignment of the $y g f K$ sequence in the databases shows some homology with the Pyrococcus abyssi glutamate synthase (36\%) and the Clostridium thermoaceticum formate dehydrogenase $(41 \%)$. Structurally, this enzyme of about $115 \mathrm{kDa}$ consists of at least three distinct domains: an $\mathrm{N}$-terminal NAD-binding domain, a central pyridine nucleotide-disulfide redox domain and a C-terminal iron-sulfur binding domain (Fig. 2A). The NADbinding domain has been found in a wide range of redox 
proteins, including alcohol dehydrogenases, amine oxidases, glutamate and other dehydrogenases. These enzymes have at least one NAD as redox cofactor that functions as an electron carrier in oxidation-reduction processes. The pyridine nucleotide-disulfide domain is actually a small NADH-binding domain within a larger FAD-binding domain present in both class I and class II disulfide oxidoreductases. These enzymes are FAD flavoproteins such as the mercuric reductase of Bacillus RC607 (Schiering et al., 1991), which contains a pair of redox-active cysteines involved in the transfer of reducing equivalents from the FAD cofactor to the substrate. The $4 \mathrm{Fe}-4 \mathrm{~S}$ centre of YgfK is similar to those of bacterial ferredoxins, various dehydrogenases and reductases, which mediate electron transfer in a wide variety of metabolic reactions. However, the complete analysis of the domain structure of YgfK does not show any similarity to known molybdopterin-binding domains. Thus, the focus was on genes present in the region of $y g f K$ (Fig. 2B). A putative operon, located downstream of $y g f K$, contains the genes $y g f M$ and $y g f N$, which encode a $28.5 \mathrm{kDa}$ and $104 \mathrm{kDa}$ protein, respectively. The YgfM polypeptide shows a FAD-binding domain found in molybdopterin dehydrogenase. The protein YgfN contains a N-terminal $[2 \mathrm{Fe}-2 \mathrm{~S}]$-binding domain and a C-terminal molybdopterin-binding domain signature. This last domain is largely described in members of the xanthine oxidase family (Ald_Xan_Dh-C2). However, a comparison of the $y g f \mathrm{~N}$ sequence in the databases shows only a low similarity to known proteins, limited to xanthine dehydrogenase (e.g. $25 \%$ from Bacillus halodurans) and aldehyde oxidoreductase (e.g. $28 \%$ from Desulfovibrio gigas). In addition, these three proteins YgfK, YgfM and YgfN are predicted to be soluble proteins without any leader peptides in their $\mathrm{N}$ terminus. These proteins might form a structural complex involved in the reduction of selenate. This proposal takes into account our finding that the selenate reductase in E. coli requires a molybdopterin cofactor and is located in the cytoplasm. This proposal is also in line with the demonstration that the selenate reductase of $T$. selenatis is composed of several polypeptides encoded by the serABDC loci (Krafft et al., 2000). Several attempts were made to provide biochemical evidence that YgfKMN is a selenate-reducing complex. Comparison of selenate-reduction activities of the soluble fractions of the wild-type and the $y g f K$ mutant was not conclusive because of the high selenate reductase activity of the nitrate reductases present in these fractions. Another approach was to measure selenate reductase activities on non-denaturating gels with benzyl viologen as electron donor for the triple mutant lacking both nar and nap genes. However, this approach was not conclusive either, since no selenate activity could be detected in this mutant although it still readily reduced selenate in vivo. A definitive proof of the selenate reductive capacity of the YgfK-YgfM-YgfN complex will therefore necessitate the characterization of mutants deleted in $y g f M$ and $y g f N$ genes and a complete in vitro functional characterization of this complex after overexpression and purification.

\section{Transport and reduction of selenite}

The strain harbouring a $c y s A$ defect still reduced selenite and tellurite with intracellular depositions. This observation confirms the existence of an alternative carrier as proposed earlier (Kredich, 1996). The conclusion that selenate and selenite are assimilated through different pathways has also been inferred for other species like Clostridium pasteurianum (Bryant \& Laishley, 1988) and Salmonella typhimurium (Brown \& Shrift, 1980). Very recently, Guzzo \& Dubow (2000) identified, in E. coli, a gene whose transcription is highly increased in the presence of tellurite or selenite. This gene, denoted gutS for gene upregulated by tellurite and selenite, encodes a polypeptide of approximately $43 \mathrm{kDa}$. This protein presents a significant homology with proteins involved in drug efflux or sugar transport. We have also proposed that in $R b$. sphaeroides the entry of selenite into the cytoplasm is mediated by a polyol transporter (Bebien $e t$ al., 2001).

Concerning the reduction of selenite, we observed that all the different mutants affected either in the synthesis of the molybdenum cofactor or in a specific molybdoenzyme are still able to reduce this compound into elemental selenium. This implies that the different steps in the reduction of selenite into elemental selenium do not involve a molybdoenzyme. In addition, intracellular accumulation of metallic selenium was not impaired in a mutant of E. coli defective in the periplasmic nitrite reductase (JCB387). Since it has been clearly shown that the soluble nitrite reductase catalyses the reduction of selenite in T. selenatis (DeMoll-Decker \& Macy, 1993), the presence of a different pathway highlights the various mechanisms developed by bacteria to reduce selenium oxyanions.

\section{Conclusion}

The present analysis of mutants impaired in selenate reduction selected from a random mini- $\operatorname{Tn} 10$ insertion library provides new insights into the mechanisms of transport and reduction of this oxyanion in E. coli. We first confirmed that selenate enters the cell through the sulfate permease, in agreement with the similarities between the chemical properties of sulfur and Se. In addition, we showed that selenate uptake into the cells also requires the transport protein $\mathrm{YbaT}$ and a functional outer-membrane porin. Our results indicated that selenate reductase in E. coli is a molybdoenzyme that differs from the various molybdoreductases described so far in this species. We propose that YgfK, YgfM and YgfN are three subunits of the selenate reductase of $E$. coli.

\section{ACKNOWLEDGEMENTS}

We are grateful to Drs L. Macaskie, J. Cole, and B. P. Rosen for supplying several mutants. We thank Dr G. Giordano for the gift of mutant strains and for a careful and critical reading of the manuscript. This work was supported by grants from the Commissariat à l'Energie Atomique ('Toxicologie $\mathrm{Nu}$ cléaire' programme). 


\section{REFERENCES}

Ansaldi, M., Bordi, C., Lepelletier, M. \& Mejean, V. (1999). TorC apocytochrome negatively autoregulates the trimethylamine $\mathrm{N}$ oxide (TMAO) reductase operon in Escherichia coli. Mol Microbiol 33, 284-295.

Avazeri, C., Turner, R. J., Pommier, J., Weiner, J. H., Giordano, G. \& Vermeglio, A. (1997). Tellurite reductase activity of nitrate reductase is responsible for the basal resistance of Escherichia coli to tellurite. Microbiology 143, 1181-1189.

Bebien, M., Chauvin, J. P., Adriano, J. M., Grosse, S. \& Vermeglio, A. (2001). Effect of selenite on growth and protein synthesis in the phototrophic bacterium Rhodobacter sphaeroides. Appl Environ Microbiol 67, 4440-4447.

Bebien, M., Lagniel, G., Garin, J., Touati, D., Vermeglio, A. \& Labarre, J. (2002). Involvement of superoxide dismutases in Escherichia coli cellular response in selenium oxides stress. J Bacteriol 184, 1556-1564.

Brown, T. A. \& Shrift, A. (1980). Assimilation of selenate and selenite by Salmonella typhimurium. Can J Microbiol 26, 671-675.

Bryant, R. D. \& Laishley, E. J. (1988). Evidence for two transporters of sulfur and selenium oxyanions in Clostridium pasteurianum. Can J Microbiol 34, 700-703.

Carlin, A., Weiping, S. H. I., Saibal, D. \& Rosen, B. P. (1995). The ars operon of Escherichia coli confers arsenical and antimonial resistance. J Bacteriol 177, 981-986.

Darwin, A., Tormay, P., Page, L., Griffiths, L. \& Cole, J. (1993). Identification of the formate dehydrogenases and the genetic determinants of formate-dependent nitrite reduction by Escherichia coli K12. J Gen Microbiol 139, 1829-1840.

DeMoll-Decker, H. \& Macy, J. M. (1993). The periplasmic nitrite reductase of Thanera selenatis may catalyze the reduction of selenite to elemental selenium. Arch Microbiol 160, 241-247.

Ganther, H. E. (1968). Formation of selenotrisulfides by the reaction of thiols with selenious acid. Biochemistry 7, 2898-2905.

Gerrard, T. L., Telford, J. N. \& Williams, H. H. (1974). Detection of selenium deposits in Escherichia coli by electron microscopy. J Bacteriol 119, 1057-1060.

Guzzo, J. \& Dubow, M. S. (2000). A novel selenite- and telluriteinducible gene in Escherichia coli. Appl Environ Microbiol 66, 4972-4978.

Hess, W. M. (1966). Fixation and staining of fungus hyphae and host plant root tissues for electron microscopy. Stain Technol 41, 27-35.

Hille, R. (1996). The mononuclear molybdenum enzymes. Chem Rev 96, 2757-2816.

Hussain, H., Grove, J., Griffiths, L., Busby, S. \& Cole, J. (1994). A seven-gene operon essential for formate-dependent nitrite reduction to ammonia by enteric bacteria. Mol Microbiol 12, 153-163.

lobbi-Nivol, C., Santini, C. L., Blasco, F. \& Giordano, G. (1990). Purification and further characterization of the second nitrate reductase of Escherichia coli K12. Eur J Biochem 188, 679-687.

Kice, J. L., Lee, T. W. S. \& Pan, S-t. (1980). Mechanism of the reaction of thiols with selenite. J Am Chem Soc 18, 102-113.

Krafft, T., Bowen, A., Theis, F. \& Macy, J. M. (2000). Cloning and sequencing of the genes encoding the periplasmic-cytochrome Bcontaining selenate reductase of Thauera selenatis. DNA Seq 10, 365-377.

Kramer, G. F. \& Ames, B. N. (1988). Mechanisms of mutagenicity and toxicity of sodium selenite $\left(\mathrm{Na}_{2} \mathrm{SeO}_{3}\right)$ in Salmonella typhimurium. Mutat Res 201, 169-180.

Kredich, N. M. (1996). Synthesis of cysteine. In Escherichia coli and Salmonella: Cellular and Molecular Biology, pp. 514-527. Edited by C. Neidhardt and others. Washington, DC: American Society for Microbiology.

Linblow-Kull, C., Kull, F. J. \& Shrift, A. (1985). Single transporter of sulfate, selenate, and selenite in Escherichia coli K-12. J Bacteriol 163, 1267-1269.

Losi, M. E. \& Frankenberger, W. T. (1997). Bioremediation of selenium in soil and water. Soil Sci 162, 692-703.

McKeehan, W. L., Hamilton, W. G. \& Ham, R. G. (1976). Selenium is an essential trace nutrient for growth of WI-38 diploid human fibroblasts. Proc Natl Acad Sci U S A 73, 2023-2027.

Moreno-Vivian, C., Cabello, P., Martinez-Luque, M., Blasco, R. \& Castillo, F. (1999). Prokaryotic nitrate reduction: molecular properties and functional distinction among bacterial nitrate reductases. J Bacteriol 181, 6573-6584.

Noda, M., Takano, T. \& Sakurai, H. (1979). Mutagenic activity of selenium compounds. Mutat Res 66, 175-179.

Ohlendorf, H. M. \& Santolo, G. M. (1994). Kesterson reservoir past, present and future: an ecological risk assessment. In Selenium in the Environment, pp. 69-117. Edited by J. R. Frankenberger \& S. Benson. New York: Marcel Dekker.

Oremland, R. S. (1994). Biogeochemical transformations of selenium in anoxic environments. In Selenium in the Environment, pp. 389-420. Edited by J. R. Frankenberger \& S. Benson. New York: Marcel Dekker.

Potter, L. C., Millington, P. D., Thomas, G. H., Rothery, R. A., Giordano, G. \& Cole, J. (2000). Novel growth characteristics and high rates of nitrate reduction of an Escherichia coli strain, LCB2048, that expresses only a periplasmic nitrate reductase. FEMS Microbiol Lett 185, 51-57.

Prinz, W. A., Åslund, F., Holmgren, A. \& Beckwith, J. (1997). The role of the thioredoxin and glutaredoxin pathways in reducing protein disulfide bonds in the Escherichia coli cytoplasm. J Biol Chem 272, 15661-15667.

Rosentel, J. K., Healy, F., Maupin-Furlow, J. A., Lee, J. H. \& Shanmugam, K. T. (1995). Molybdate and regulation of mod (molybdate transport) $f d h F$, and $h y c$ (formate hydrogenlyase) operons in Escherichia coli. J Bacteriol 177, 4857-4864.

Roux, M., Sarret, G., Pignot-Paintrand, I., Fontecave, M. \& Coves, J. (2001). Mobilization of selenite by Ralstonia metallidurans CH34. Appl Environ Microbiol 67, 769-773.

Sabaty, M., Avazeri, C., Pignol, D., Adriano, J. M. \& Vermeglio, A. (2001). Characterization of the reduction of selenate and tellurite by nitrate reductases. Appl Environ Microbiol 67, 5122-5126.

Saiki, M. K. \& Lowe, T. P. (1987). Selenium in aquatic organisms from subsurface agricultural drainage water, San Joaquin Valley, California. Arch Environ Contam Toxicol 16, 657-670.

Schiering, N., Kabsch, W., Moore, M. J., Distefano, M. D., Walsh, C. T. \& Pai, E. F. (1991). Structure of the detoxification catalyst mercuric ion reductase from Bacillus sp. strain RC607. Nature 352, 168-172.

Schröder, I., Rech, S., Krafft, T. \& Macy, J. M. (1997). Purification and characterization of the selenate reductase from Thauera selenatis. J Biol Chem 272, 23765-23768.

Seko, Y. \& Imura, N. (1997). Active oxygen generation as a possible mechanism of selenium toxicity. Biomed Environ Sci 10, 333-339.

Shamberger, R. J. (1983). The biochemistry of selenium. In 
Selenium in Biology, pp. 1-334. Edited by E. Frieden. New York: Plenum.

Silverberg, B. A., Wong, P. T. S. \& Chau, Y. K. (1976). Localization of selenium in bacterial cells using TEM and energy dispersive Xray analysis. Arch Microbiol 107, 1-6.

Smith, F. W., Hawkesford, M. J., Prosser, I. M. \& Clarkson, D. T. (1995). Isolation of cDNA from Saccharomyces cerevisiae that encodes a high affinity sulfate transporter at the plasma membrane. Mol Gen Genet 247, 709-715.

Stadtman, T. C. (1974). Selenium biochemistry. Science 183, 915-922.

Stadtman, T. C. (1996). Selenocysteine. Annu Rev Biochem 65, 83-100.

Stewart, V. \& MacGregor, C. H. (1982). Nitrate reductase in
Escherichia coli K-12: involvement of chlC, chlE, and chlG loci. J Bacteriol 151, 788-799.

Turner, R. J., Weiner, J. H. \& Taylor, D. E. (1998). Selenium metabolism in Escherichia coli. Biometals 11, 223-227.

Van Fleet-Stalder, V., Chasteen, T. G., Pickering, I. J., George, G. N. \& Prince, R. C. (2000). Fate of selenate and selenite metabolized by Rhodobacter sphaeroides. Appl Environ Microbiol 66, 4849-4853.

Yamada, A., Miyashita, M., Inoue, K. \& Matsunaga, T. (1997). Extracellular reduction of selenite by a novel marine photosynthetic bacterium. Appl Microbiol Biotechnol 48, 367-372.

Received 18 April 2002; revised 22 July 2002; accepted 27 August 2002. 